\title{
Effect of intensified feeding of heifer calves on growth, pubertal age, calving age, milk yield, and economics
}

\author{
L. E. Davis Rincker, ${ }^{* 1}$ M. J. VandeHaar, ${ }^{*}$ C. A. Wolf, $†$ J. S. Liesman, ${ }^{*}$ L. T. Chapin, ${ }^{\star}$ and M. S. Weber Nielsen ${ }^{\star 2}$ \\ *Department of Animal Science, and \\ †Department of Agricultural Economics, Michigan State University, East Lansing 48824
}

\begin{abstract}
The objective of this study was to determine if increasing the energy and protein intake of heifer calves would affect growth rates, age at puberty, age at calving, and first lactation milk yield. A second objective was to perform an economic analysis of this feeding program using feed costs, number of nonproductive days, and milk yield data. Holstein heifer calves born at the Michigan State Dairy Cattle Teaching and Research Center were randomly assigned to 1 of 2 dietary treatments $(\mathrm{n}=40 /$ treatment $)$ that continued from 2 $\mathrm{d}$ of age until weaning at $42 \mathrm{~d}$ of age. The conventional diet consisted of a standard milk replacer $[21.5 \%$ crude protein (CP), $21.5 \%$ fat] fed at $1.2 \%$ of body weight (BW) on a dry matter basis and starter grain $(19.9 \%$ $\mathrm{CP})$ to attain $0.45 \mathrm{~kg}$ of daily gain. The intensive diet consisted of a high-protein milk replacer $(30.6 \% \mathrm{CP}$, $16.1 \%$ fat) fed at $2.1 \%$ of BW on a dry matter basis and starter grain $(24.3 \% \mathrm{CP})$ to achieve $0.68 \mathrm{~kg}$ of daily gain. Calves were gradually weaned from milk replacer by decreasing the amount offered for 5 and $12 \mathrm{~d}$ before weaning for the conventional and intensive diets, respectively. All calves were completely weaned at $42 \mathrm{~d}$ of age and kept in hutches to monitor individual starter consumption in the early postweaning period. Starting from 8 wk of age, heifers on both treatments were fed and managed similarly for the duration of the study. Body weight and skeletal measurements were taken weekly until 8 wk of age, and once every 4 wk thereafter until calving. Calves consuming the intensive diet were heavier, taller, and wider at weaning. The difference in withers height and hip width was carried over into the early post-weaning period, but a $\mathrm{BW}$ difference was no longer evident by 12 wk of age. Calves fed the intensive diet were younger and lighter at the onset of puberty. Heifers fed the high-energy and protein diet
\end{abstract}

\footnotetext{
Received October 11, 2010.

Accepted January 13, 2011

${ }^{1}$ Current address: Department of Agriculture, Eastern Kentucky University, Richmond.

${ }^{2}$ Corresponding author: msw@msu.edu
}

were $15 \mathrm{~d}$ younger at conception and $14 \mathrm{~d}$ younger at calving than heifers fed the conventional diet. Body weight after calving, daily gain during gestation, withers height at calving, body condition score at calving, calving difficulty score, and calf BW were not different. Energy-corrected, age-uncorrected 305-d milk yield was not different, averaging 9,778 $\mathrm{kg}$ and 10,069 $\mathrm{kg}$ for heifers fed the conventional and intensive diets, respectively. However, removing genetic variation in milk using parent average values as a covariate resulted in a tendency for greater milk from heifers fed the intensive diet. Preweaning costs were higher for heifers fed the intensive diet. However, total costs measured through first lactation were not different. Intensified feeding of calves can be used to decrease age at first calving without negatively affecting milk yield or economics.

Key words: calf, nutrition, milk replacer

\section{INTRODUCTION}

Feeding high-energy diets for rapid growth rates enables heifers to achieve breeding size earlier, potentially decreasing age at calving and costs associated with raising replacement heifers (Radcliff et al., 2000; Raeth-Knight et al., 2009). However, mammary growth relative to body growth is decreased when heifers approximately 3 to 10 mo of age are fed high-energy diets, resulting in overconditioned heifers with decreased milk yield potential (Sejrsen et al., 1982; Petitclerc et al., 1999; Radcliff et al., 2000). This age range coincides with a period of allometric mammary growth relative to overall body growth (Sinha and Tucker, 1969). Little is known about how consumption of higher-energy and higher-protein milk replacers by calves before 3 mo of age affects mammary growth and milk yield.

Previous research indicates that increasing the protein and energy intake of calves during the preweaning period increases body size and mammary growth and also improves milk yield. In one study, calves were either allowed to suckle the dam 3 times per d or were fed milk replacer for the first 6 wk of age. Calves allowed to suckle had higher daily gains during the treatment period and also tended to produce more milk during their 
first lactation (Bar-Peled et al., 1997). In a more recent study, calves were either fed milk replacer resulting in gains of $0.59 \mathrm{~kg} / \mathrm{d}$ or given free access to whole milk for two 30-min intervals/d for gains of $0.88 \mathrm{~kg} / \mathrm{d}$ (Shamay et al., 2005). Feeding whole milk to calves increased BW but not skeletal size of the adult animal and increased FCM yield by $4 \%$ during first lactation compared with calves fed milk replacer. However, in these studies it is difficult to determine if feeding method, quantity consumed, or potential factors in whole milk compared with milk replacer played a role in observed differences in milk yield. Work from our laboratory demonstrated that consumption of a higher-energy and higher-protein milk replacer by calves increases mammary development before weaning. In this study, calves that gained 0.67 $\mathrm{kg} / \mathrm{d}$ from 2 to 8 wk of age had increased body growth and almost twice the amount of mammary parenchymal DNA as calves that gained $0.38 \mathrm{~kg} / \mathrm{d}$ (Brown et al., 2005a,b). Limited research exists that has demonstrated long-term effects of an intensified milk replacer feeding program on growth, age at calving, and milk yield (Raeth-Knight et al., 2009). The Raeth-Knight study demonstrated that calves fed a high-protein and high-energy milk replacer with high solids had greater BW and height at $112 \mathrm{~d}$ of age, calved earlier, but did not have greater milk yield than did calves fed a conventional milk replacer. The objective of our study was to determine if increasing the energy and protein intake in milk replacer of preweaned calves would affect long-term body growth, age at puberty, age at calving, and first lactation milk yield. A second objective was to perform an economic analysis of the feeding programs using feed costs, number of nonproductive days, and milk yield data.

\section{MATERIALS AND METHODS}

\section{Animals and Dietary Treatments}

All procedures were approved by the Michigan State University Animal Use and Care Committee (08/00110-00). Holstein heifer calves $(\mathrm{n}=80)$ born at the Michigan State University Dairy Cattle Teaching and Research Center (East Lansing) from October 2002 through December 2003 were randomly assigned to 1 of 2 dietary treatments. All calves were fed 2 feedings of colostrum within the first 4 and $16 \mathrm{~h}$ of life. The first feeding consisted of $3 \mathrm{~L}$ of high-quality colostrum, measuring at least $50 \mathrm{~g} / \mathrm{L}$ in immunoglobulin concentration by a colostrometer (Biogenics, Mapleton, OR). The second feeding of colostrum consisted of $1.9 \mathrm{~L}$. The umbilicus was drenched with a $7 \%$ iodine solution at birth. Treatments began at $2 \mathrm{~d}$ of age and concluded when calves were weaned at $42 \mathrm{~d}$ of age. Calves were housed in individual calf hutches and were not allowed nose-to-nose contact. During the treatment period, milk replacer was fed at approximately 0800 and 1800 $\mathrm{h}$ and refusals were recorded at each feeding. Calves were transitioned from a bottle to a bucket within a few days of age. Starter grain was fed at $0800 \mathrm{~h}$ and refusals were recorded once daily. Starter diet was changed if it was wet or if not fresh. Limited amounts of starter were fed, although calves rarely consumed the full amount offered. Calves were allowed ad libitum access to water and water was changed daily. The conventional diet consisted of milk replacer (Calvita Supreme; MSC Specialty Nutrition Co., Dundee, IL; $21.5 \%$ CP, $21.5 \%$ fat; nonmedicated; Table 1) fed on a DM basis at $1.2 \%$ of BW based on weekly BW (reconstituted to $12.5 \%$ solids). Starter grain (19.9\% CP; Kent Feeds, Muscatine, IA; Table 2) was fed to achieve $0.45 \mathrm{~kg}$ of ADG. The intensive diet consisted of a high-protein milk replacer (Excelerate; MSC Specialty Nutrition Co.; 30.6\% CP, $16.1 \%$ fat; nonmedicated) fed on a DM basis at $2.1 \%$ of BW based on weekly weighings (reconstituted to $15 \%$ solids). Milk replacer was reconstituted differently between treatments due to the larger total volume of milk replacer fed to the calves on the intensive diet. Starter grain $(24.3 \%$ CP; Kent Feeds) was fed to achieve 0.68 $\mathrm{kg}$ of ADG. Calves fed the intensive diet received 0.69 $\mathrm{kg}$ milk replacer powder/d on a DM basis during the first week due to too much volume of milk if these calves had been fed according to the $2.1 \%$ of BW basis. Twicedaily feedings of milk replacer was decreased during the last 12 and $5 \mathrm{~d}$ for intensive and conventional calves, respectively, to gradually wean calves completely by 42 $\mathrm{d}$ of age. Calves fed the intensive diet received $1.12 \mathrm{~kg}$ milk replacer powder/d on a DM basis from d 31 to 37 , and $0.69 \mathrm{~kg}$ milk replacer powder/d from d 38 to 42 . Calves fed the conventional diet received $0.58 \mathrm{~kg}$ milk replacer powder/d on a DM basis from d 38 to 42 . In addition, the amount of milk replacer fed was increased during cold weather using equations of the National Research Council (NRC, 2001).

Blood samples were taken between 48 and $60 \mathrm{~h}$ of age for determination of serum IgG concentration (Bovine IgG Radial Immunodiffusion Kit, VMRD Inc., Pullman, WA). Rectal temperatures and fecal scores $(1=$ firm and dry; $2=$ soft; $3=$ pudding-like; $4=$ soft and watery mixture; $5=$ watery) were recorded daily during the first $2 \mathrm{wk}$ of the treatment period and also when a calf appeared ill. Days that calves were medicated during the treatment period and post-treatment period were recorded. Body weights, hip width using a hipometer (Dingwell et al., 2006), and withers height measurements were taken once weekly during the treatment period. Initial BW measurements were taken at $2 \mathrm{~d}$ of age. Initial hip width and withers height measurements 
Table 1. Chemical composition of milk replacer on a DM basis ${ }^{1}$

\begin{tabular}{|c|c|c|}
\hline Variable & $\begin{array}{c}\text { Conventional } \\
\text { diet }^{2}\end{array}$ & $\begin{array}{c}\text { Intensive } \\
\text { diet }^{3}\end{array}$ \\
\hline CP $(\%)$ & 21.5 & 30.6 \\
\hline Crude fat (\%) & 21.5 & 16.1 \\
\hline Crude fiber (\%) & 0.16 & 0.16 \\
\hline Ca minimum (\%) & 0.80 & 0.81 \\
\hline Ca maximum (\%) & 1.34 & 1.34 \\
\hline $\mathrm{P}(\%)$ & 0.75 & 0.64 \\
\hline Vitamin A (IU/kg) & 70,937 & 17,755 \\
\hline Vitamin D (IU/kg) & 23,646 & 5,918 \\
\hline Vitamin E (IU/kg) & 473 & 118 \\
\hline
\end{tabular}

${ }^{1}$ Feed manufacturer's guaranteed analysis.

${ }^{2}$ Calvita Supreme (MSC Specialty Nutrition, Dundee, IL).

${ }^{3}$ High-energy and high-protein diet (Excelerate; MSC Specialty Nutrition).

were taken at wk 1 because calves were too unstable to get accurate measurements at $2 \mathrm{~d}$ of age. Weekly BW measurements taken during the treatment period were used to adjust the amount of milk replacer fed. Calves were vaccinated against bovine rhinotracheitis and

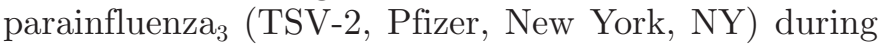
the treatment period. All calves were dehorned during the last $2 \mathrm{wk}$ of the treatment period using a propane electric dehorner. Calves were retained in the study after weaning if they grew at the targeted ADG $( \pm 0.1$ $\mathrm{kg}$ ) for their dietary treatment as averaged from 2 to $42 \mathrm{~d}$ of age. This study was designed to achieve growth rates similar to the Brown et al. (2005a,b) study to allow comparison of results to this study. Of the 19 calves eliminated from the study, 12 calves had healthrelated problems, 4 calves had low starter intake, and for 3 of the calves the reason for low rate of gain was undetermined.

\section{Post-Treatment Management}

After weaning, heifer calves from both treatments were commingled and managed the same according to standard operating procedures of the facility. Calves were housed in individual hutches until $8 \mathrm{wk}$ of age so that starter consumption during the early post-weaning period could be measured. Calves were transitioned from the starter grain consumed during the treatment period to the starter grain fed during the post-weaning period. This was done by mixing $50 \%$ of the starter grain received during the treatment period and $50 \%$ of another grain mixture (Intense Calf TCR B60, Land O' Lakes, St. Paul, MN; see Table 2 for analysis) for the first $5 \mathrm{~d}$ after weaning. At 8 wk of age, calves were moved into a group pen. Measurements of BW, hip width, and withers height were taken weekly during wk 7 and 8 and then were taken once every 4 wk until parturition.

From 8 wk until 3 mo of age, heifers were fed 2.7 $\mathrm{kg}$ starter grain per d (Intense Calf TCR B60, Land O' Lakes) and were allowed ad libitum access to alfalfa hay. At 3 mo of age, heifers were transitioned to a TMR. Composition of the TMR that were fed from 3 mo of age through lactation is provided in Tables 3 and 4 . Heifers were fed a TMR during gestation except during the warmer months (early May to late August) when pregnant heifers were allowed to graze pasture. Close-up and lactating primiparous heifers were individually fed to allow for approximately $10 \%$ refusals.

To determine the age and $\mathrm{BW}$ at the onset of $\mathrm{pu}-$ berty, heifers were weighed weekly once they reached $204 \mathrm{~kg}$ of BW. Blood samples were taken weekly for determination of serum progesterone concentration

Table 2. Chemical composition of starter grain on a DM basis ${ }^{1}$

\begin{tabular}{|c|c|c|c|}
\hline Variable & $\begin{array}{c}\text { Conventional } \\
\text { diet }^{2}\end{array}$ & $\begin{array}{c}\text { Intensive } \\
\text { diet }^{3}\end{array}$ & $\begin{array}{c}\text { Post-treatment } \\
\text { diet }^{4}\end{array}$ \\
\hline $\mathrm{CP}(\%)$ & 19.9 & 24.3 & 22.2 \\
\hline Crude fat $(\%)$ & 3.32 & 3.31 & 2.22 \\
\hline Crude fiber (\%) & 7.74 & 7.73 & 13.59 \\
\hline $\operatorname{ADF}(\%)$ & 9.96 & 9.94 & 17.78 \\
\hline Ca minimum (\%) & 0.55 & 1.10 & 0.67 \\
\hline Ca maximum (\%) & 1.11 & 1.66 & 1.22 \\
\hline $\mathrm{P}(\%)$ & 0.55 & 0.66 & 0.61 \\
\hline Salt minimum (\%) & 0.22 & 0.22 & * \\
\hline Salt maximum (\%) & 0.77 & 0.77 & * \\
\hline $\mathrm{Se}(\mathrm{mg} / \mathrm{kg})$ & 0.33 & 0.33 & 0.33 \\
\hline Vitamin A (IU/kg) & 24,386 & 26,904 & 15,324 \\
\hline Vitamin $\mathrm{D}_{3}(\mathrm{IU} / \mathrm{kg})$ & 4,146 & 4,140 & 3,065 \\
\hline Vitamin E (IU/kg) & 219 & 219 & 61 \\
\hline
\end{tabular}


Table 3. Ingredient and chemical composition of post-treatment diets

\begin{tabular}{|c|c|c|c|c|}
\hline \multirow[b]{2}{*}{ Item } & \multicolumn{4}{|c|}{ Post-treatment diet } \\
\hline & $3-5 \mathrm{mo}$ & $5-10 \mathrm{mo}$ & Breeding & Gestation $^{1}$ \\
\hline \multicolumn{5}{|l|}{ Ingredient ( $\%$ of $\mathrm{DM})$} \\
\hline Alfalfa hay & 30.6 & 18.5 & - & - \\
\hline Alfalfa silage & 34.7 & 51.7 & 54.8 & 65.8 \\
\hline Bovatec mix $^{2}$ & 9.8 & 12.9 & - & - \\
\hline Calf starter ${ }^{3}$ & 16.7 & - & - & - \\
\hline Corn silage & - & - & 10.2 & 10.1 \\
\hline Grass hay & - & - & - & 9.7 \\
\hline Heifer Developer $45^{4}$ & 2.8 & 8.2 & 8.6 & 6.8 \\
\hline Soybean meal (48\% CP) & - & - & - & 4.5 \\
\hline Spelt hulls & 5.6 & 8.8 & 13.7 & 3.0 \\
\hline Wheat silage & - & - & 12.7 & - \\
\hline \multicolumn{5}{|c|}{ Nutrient composition (DM basis) } \\
\hline $\operatorname{NDF}(\%)$ & 37.2 & 38.5 & 50.4 & 52.7 \\
\hline $\operatorname{ADF}(\%)$ & 26.4 & 27.3 & 35.0 & 34.7 \\
\hline $\mathrm{ME}^{5}(\mathrm{Mcal} / \mathrm{kg})$ & 2.43 & 2.19 & 1.87 & 2.05 \\
\hline $\mathrm{NE}_{\mathrm{M}}(\mathrm{Mcal} / \mathrm{kg})$ & 1.52 & 1.37 & 1.17 & 1.28 \\
\hline $\mathrm{NE}_{\mathrm{G}}(\mathrm{Mcal} / \mathrm{kg})$ & 0.93 & 0.73 & 0.60 & 0.60 \\
\hline $\mathrm{CP}(\%)$ & 20.2 & 20.6 & 18.0 & 16.4 \\
\hline RUP (\% of CP) & 27.9 & 25.4 & 23.6 & 25.3 \\
\hline $\mathrm{RDP}(\%$ of $\mathrm{CP})$ & 72.2 & 74.6 & 76.4 & 74.8 \\
\hline
\end{tabular}

(Coat-A-Count Progesterone In vitro Diagnostic Test Kit, DPC, Los Angeles, CA). The onset of puberty was determined to be when serum progesterone concentration exceeded $1 \mathrm{ng} / \mathrm{mL}$ for 2 consecutive weeks.

Heifers became eligible for breeding at $397 \mathrm{~kg}$ of BW and BCS were taken at this time $(1=$ thin to $5=$ fat $)$ by an experienced examiner. Heifers were administered Lutalyse (Pfizer) on $\mathrm{d} 1$ of the breeding protocol. If heifers were exhibiting signs of estrus, they were bred by artificial insemination. If not found in estrus, an Eazi-Breed CIDR (Pfizer) was inserted into the vagina on d 10, Lutalyse was administered on d 15, the CIDR was removed on $\mathrm{d} 16$, and then heifers were bred after observation of estrus. Heifers were examined for pregnancy by ultrasound $30 \mathrm{~d}$ after insemination, unless the heifer was observed in estrus before this time. Heifers were allowed 3 services to conceive before being eliminated from the study.

Heifers were vaccinated according to the standard operating procedure of the farm. At 4 to 8 mo of age, heifers were vaccinated for brucellosis. Heifers were vaccinated twice per year for infectious bovine rhinotracheitis, bovine viral diarrhea, parainfluenza 3 , leptospirosis, and bovine respiratory syncytial virus (Bovi-Shield FP $4+$ L5, Pfizer) and for Clostridium chauvoei-septicumnovyi-sordellii-perfringens types $\mathrm{B}, \mathrm{C}$, and D and
Haemophilus somnus bacterin (Ultrabac7/Somubac, Pfizer). A total of 3 vaccinations of J5 Escherichia coli bacterin (Pfizer) were administered at approximately 30 and $60 \mathrm{~d}$ before calving and 2 wk after calving.

Body weights were recorded twice weekly during the 3 wk before calving. Withers height and BCS were also recorded before calving. Body weights of primiparous heifers were recorded before feeding on d 2 and d 3 after calving. Calving difficulty score $(1=$ no assistance; 2 $=$ slight assistance; $3=$ some assistance $4=$ considerable force; $5=$ extreme difficulty) was recorded at the time of calving. Calf BW was recorded at $1 \mathrm{~d}$ of age. Primiparous heifers were milked twice daily and milk weights were recorded electronically. At 150 DIM, BW and withers heights were recorded. Daily milk weights and health data (diagnosis, treatments, date of incident) were recorded during the first 150 DIM. Health events during lactation were recorded. Milk protein and butterfat percentage and SCC were measured monthly for individual animals by DHIA. Milk yield data collected for a minimum of 150 DIM was used to calculate projected 305-d mature equivalent (MEq) ECM. End of lactation 305-d MEq milk data was uncorrected for maturity but not season by dividing the 305-d MEq milk value by the appropriate average of the 12 monthly coefficients for an age in the milk, protein, 
Table 4. Ingredient and chemical composition of post-treatment diets

\begin{tabular}{|c|c|c|c|c|}
\hline \multirow[b]{2}{*}{ Item } & \multicolumn{4}{|c|}{ Post-treatment diet } \\
\hline & Close-up & Fresh & $\operatorname{High}^{1}$ & Moderate \\
\hline \multicolumn{5}{|l|}{ Ingredient ( $\%$ of $\mathrm{DM})$} \\
\hline Alfalfa hay & - & 7.9 & 5.4 & 5.4 \\
\hline Alfalfa silage & 26.8 & 18.5 & 13.2 & 16.2 \\
\hline Beet pulp & 11.7 & - & - & - \\
\hline Corn silage & 19.4 & 19.7 & 21.4 & 33.7 \\
\hline Cottonseed with lint & - & 6.3 & 6.8 & - \\
\hline Energy Booster ${ }^{2}$ & - & - & 1.0 & - \\
\hline Grass hay & 6.4 & - & - & - \\
\hline Ground corn & - & 17.6 & 27.0 & 23.4 \\
\hline Rally $^{3}$ & 4.3 & 2.7 & - & - \\
\hline Soy Chlor ${ }^{4}$ & 10.7 & - & - & - \\
\hline Soybean meal ( $48 \%$ CP) & 7.2 & 12.8 & 12.7 & 12.9 \\
\hline Spelt hulls & 9.4 & - & - & - \\
\hline UltEXT 24/365 & - & - & 3.9 & - \\
\hline Vitamin/mineral $\operatorname{mix}^{6}$ & 4.1 & 14.4 & - & 8.4 \\
\hline \multicolumn{5}{|c|}{ Nutrient composition (DM basis) } \\
\hline NDF $(\%)$ & 43.8 & 30.5 & 26.3 & 31.7 \\
\hline $\operatorname{ADF}(\%)$ & 28.1 & 19.3 & 17.1 & 19.1 \\
\hline ME7 (Mcal/kg) & 2.43 & 2.75 & 2.90 & 2.67 \\
\hline $\mathrm{NE}_{\mathrm{L}}(\mathrm{Mcal} / \mathrm{kg})$ & & 1.68 & 1.74 & 1.63 \\
\hline $\mathrm{NE}_{\mathrm{M}}(\mathrm{Mcal} / \mathrm{kg})$ & 1.52 & 1.72 & 1.81 & 1.67 \\
\hline $\mathrm{NE}_{\mathrm{G}}(\mathrm{Mcal} / \mathrm{kg})$ & 0.93 & 1.10 & 1.21 & 1.08 \\
\hline $\mathrm{CP}(\%)$ & 15.9 & 18.9 & 18.9 & 17.9 \\
\hline RUP (\% of CP) & 33.4 & 33.9 & 32.7 & 30.2 \\
\hline $\mathrm{RDP}(\%$ of $\mathrm{CP})$ & 66.6 & 66.1 & 67.3 & 69.9 \\
\hline
\end{tabular}

${ }^{1}$ The high diet was balanced for lactating primiparous heifers producing approximately $41 \mathrm{~kg}$ of milk, whereas the moderate diet was balanced for lactating primiparous heifers producing $36 \mathrm{~kg}$ of milk or less.

${ }^{2}$ Energy Booster (MSC Specialty Nutrition Co., Dundee, IL)

${ }^{3}$ Rally (Land O' Lakes, St. Paul, MN)

${ }^{4}$ Soy Chlor (West Central Cooperative, Ralston, IA)

${ }^{5}$ UltEXT 24/36 (Purina Mills, Gray Summit, MO)

${ }^{6}$ The mineral and vitamin mix was formulated so that the diet provided $100 \%$ of mineral and vitamin requirements.

${ }^{7}$ Calculated using equation: $\mathrm{ME}(\mathrm{Mcal} / \mathrm{kg}$ of $\mathrm{DM})=\mathrm{NE}_{\mathrm{m}}(\mathrm{Mcal} / \mathrm{kg}$ of $\mathrm{DM}) \times 1.6$.

and fat tables (Norman et al., 1974). Parent average (PA) values for milk from each animal were used as a covariate to analyze milk yield.

\section{Animal Numbers}

A total of 80 heifer calves were weaned. Nineteen calves started the study but did not achieve targets for ADG at weaning and were replaced. Nineteen heifers were excluded during the post-treatment period. Reasons for exclusion (and number excluded from each diet group) included: health/disease (conventional $=2$ ), late attainment of puberty (intensive $=1,>397 \mathrm{~kg}$ of BW), failure to conceive within 3 services (conventional $=4$; intensive $=2$ ), abortion (conventional $=1$; intensive $=$ 3 ), low milk yield/nonfunctional quarters (conventional $=3$; intensive $=2$ ), and lameness (conventional $=1$ ). A total of 11 heifers from the conventional diet and 8 heifers from the intensive diet were removed from the study in the post-treatment period. Data from animals dropped during the post-treatment period were included in the analysis until the age at which they were eliminated from the study.

\section{Economics}

Milk replacer and starter grain costs were based on actual costs averaged over 2 yr. Conventional milk replacer was estimated at $\$ 2.22 / \mathrm{kg}$ and intensive milk replacer was $\$ 2.63 / \mathrm{kg}$. Starter costs were $\$ 0.43 /$ $\mathrm{kg}$ and $\$ 0.45 / \mathrm{kg}$ for conventional and intensive diet, respectively (data not included). Assumptions for the economic analyses are given as footnotes in Table 11. These costs were derived by taking the average expenses from 4 sources: Radcliff et al. (1997), Pennsylvania State University College of Agricultural Sciences Agricultural Research and Cooperative Extension (2000), Harsh et al. (2001), and Dhuyvetter et al. (2005). Most costs other than feed are assumed to be constant/day during heifer growth. The costs of labor, utilities and 
Table 5. Effect of preweaning diet on health indices of calves $(n=40$ in each diet group)

\begin{tabular}{|c|c|c|c|c|}
\hline \multirow{2}{*}{$\begin{array}{l}\text { Health } \\
\text { indicator }\end{array}$} & \multicolumn{2}{|c|}{ Preweaning diet } & \multirow[b]{2}{*}{ SEM } & \multirow[b]{2}{*}{$P$-value } \\
\hline & Conventional & Intensive $^{1}$ & & \\
\hline 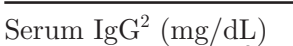 & 2,664 & 2,550 & 89.5 & 0.37 \\
\hline Days with $>39.4^{\circ} \mathrm{C}^{3}$ & 1.18 & 1.25 & 0.22 & 0.81 \\
\hline Fecal score ${ }^{3}(1-5)$ & 3.01 & 3.21 & 0.07 & 0.03 \\
\hline Days with loose stool $^{3}$ & 2.79 & 4.04 & 0.29 & $<0.01$ \\
\hline Days medicated & 2.38 & 2.73 & 0.62 & 0.69 \\
\hline
\end{tabular}

${ }^{1}$ High-energy and high-protein diet.

${ }^{2}$ Blood samples were taken between 48 and $60 \mathrm{~h}$ after birth for IgG analysis.

${ }^{3}$ Rectal temperature and fecal consistency were recorded daily during the first 2 wk of the treatment period. Fecal scores were rated as follows: $1=$ firm and dry; $2=$ soft; $3=$ pudding-like; $4=$ soft and watery mixture; $5=$ watery.

fuel, supplies, other variables, and fixed expenses (depreciation, interest, repairs, taxes, and insurance) were spread uniformly across months on an average daily cost basis and were assumed to increase with more days until first calving. Breeding and medical expenses were assumed to be independent of number of days until first calving. Feed costs after weaning and through lactation were estimated by predicting $\mathrm{ME}$ or $\mathrm{NE}_{\mathrm{L}}$ requirements from NRC (2001) based on the BW, change in BW, and milk energy output for each animal and using standard Midwest US prices per Mcal of $\mathrm{ME}$ or $\mathrm{NE}_{\mathrm{L}}$, and assuming that treatment did not alter efficiency between weaning and the end of first lactation. Milk price used was $\$ 0.36 / \mathrm{kg}$ (approximately $\$ 16 / 45.4 \mathrm{~kg}$ ), which was the average all milk price for the United States from 2004 through 2008 (USDA-NASS, 2008).

Due to the duration that capital is committed to heifers before them becoming productive assets, the rate and method of investment in heifer growth is an important decision. With cash outflows and inflows taking place at different times and rates depending on the age at first calving, net future value analysis (capital budgeting) is used to examine the effects in current dollars. Comparisons of heifer growth investments at conventional and intensive growth rates followed through the first 10 mo (305 d) of lactation were made by calculating the future value of each. The future value is the amount a present value will become at some future date. Because the timing of expense and revenues varies by growth rate, comparing the values necessitates putting the values at the same end time. The net future value (NFV) is computed by summing the future value of the cash flows (revenues net of expenses for each month summed over the period of the investment) using the appropriate compound rate. The NFV is calculated as

$$
\mathrm{NFV}=\sum_{\mathrm{t}=0}^{\mathrm{T}}\left[\left(\mathrm{I}_{\mathrm{t}}-\mathrm{E}_{\mathrm{t}}\right)(1+\mathrm{r})^{\mathrm{t}}\right]
$$

where $\mathrm{I}=$ monthly revenue (cash inflows), $\mathrm{E}=$ monthly expense (cash outflows), $\mathrm{t}=$ monthly index, $\mathrm{r}=$ the compound rate, $\mathrm{T}=$ the length of the investment. Here, $\mathrm{r}$ is set at $10 \%$ and $\mathrm{T}$ is set at the age at first calving plus the first $152 \mathrm{~d}$ of lactation (midpoint of $305 \mathrm{~d}$ ) for net milk returns and total milk plus heifer returns.

\section{Statistical Analysis}

Statistical analysis used the PROC GLM procedure of SAS (SAS Institute, 2004). Heifer was used as the experimental unit. Least squares means and standard errors of the mean are presented. Statistical significance was declared at $P<0.05$ and tendency at $P<0.10$.

Data that was collected every week or every $4 \mathrm{wk}$ was treated as a repeated measure and analyzed using PROC MIXED with either compound symmetry or first-order autoregressive as the covariance structure. Growth data was adjusted so that data reflected measurements at a particular age. After 8 wk of age, heifers were weighed once every $4 \mathrm{wk}$ on weigh days that occurred twice per month (every $2 \mathrm{wk}$ ). Therefore, adjustments were done with SAS so that data reflected measurements at ages: 56, 84, and $112 \mathrm{~d}$, and every 28 $\mathrm{d}$ thereafter.

\section{RESULTS}

\section{Health}

Serum IgG from samples taken 48 to $60 \mathrm{~h}$ after birth indicated that calves had successful passive transfer of immunity and values were not different between treatments (Table $5 ; P=0.37$ ). Calves fed the intensive diet during the preweaning period had higher fecal scores during the first 2 wk of the study and had more days with loose stools $(P=0.03$ and $P<0.01$, respectively). However, days with a fever and days medicated were not different between treatments $(P>0.6)$.

\section{Feed Intake}

Calves fed the intensive diet consumed more milk replacer, but consumed less starter grain than did calves fed the conventional diet during the preweaning period (Table $6 ; P<0.01$ ). Starter grain consumption during the 2 wk after weaning was not different between treatments $(P=0.58)$.

\section{Body Growth}

Daily gain averaged during the treatment period was 0.44 and $0.64 \mathrm{~kg}$ for calves on the conventional and 
Table 6. Effect of preweaning diet on DMI of calves $(\mathrm{n}=40$ in each diet group $)^{1}$

\begin{tabular}{lccrr}
\hline & \multicolumn{2}{c}{ Preweaning diet } & & \\
\cline { 2 - 3 } DMI $(\mathrm{kg})$ & Conventional & Intensive $^{2}$ & SEM & $P$-value \\
\hline Milk replacer & $0.60^{3}$ & $1.03^{4}$ & 0.01 & $<0.01$ \\
Starter grain & 0.39 & 0.20 & 0.01 & $<0.01$ \\
Starter grain 6-8 wk & 2.33 & 2.29 & 0.06 & 0.58 \\
\hline
\end{tabular}

${ }^{1}$ The chemical compositions of the milk replacer and starter grain can be found in Table 1 and Table 2, respectively.

${ }^{2}$ High-energy and high-protein diet.

${ }^{3}$ Daily intake of milk replacer averaged $0.51,0.55,0.59,0.60,0.63$, and $0.64 \mathrm{~kg}$ for wk $1,2,3,4,5$, and 6 , respectively.

${ }^{4}$ Daily intake of milk replacer averaged $0.69,0.93,1.09,1.17,1.20$, and $0.89 \mathrm{~kg}$ for wk $1,2,3,4,5$, and 6 , respectively.

intensive diets, respectively (Table $7 ; P<0.01$ ). Daily gain averaged each wk until 8 wk of age was higher for calves fed the intensive diet compared with calves fed the conventional diet at the end of wk $1,2,3$, and 4 (Figure 1; $P<0.05$ ). However, calves fed the conventional diet gained more during wk 6 and $7(P<0.05)$. Gain:feed ratios were higher for calves consuming the intensive diet during the preweaning period $(P<0.01)$ and were similar to those previously reported in calves with similar treatments (Brown et al., 2005b). Calves consuming the intensive diet were more efficient in converting feed to gain during the preweaning period.

Initial BW at $2 \mathrm{~d}$ of age and hip width and withers height measurements taken at 1 wk of age were not different between the 2 treatments (Table $7 ; P>0.3$ ). Increasing the energy and protein intake during the preweaning period resulted in larger calves at $1 \mathrm{wk}$ of age and taller and wider calves from 2 until 6 wk of age when calves were weaned and treatments ended (Figure

Table 7. Effect of preweaning diet on growth $(\mathrm{n}=40$ in each diet group)

\begin{tabular}{|c|c|c|c|c|}
\hline \multirow[b]{2}{*}{ Growth } & \multicolumn{2}{|c|}{ Preweaning diet } & \multirow[b]{2}{*}{ SEM } & \multirow[b]{2}{*}{$P$-value } \\
\hline & Conventional & Intensive $^{1}$ & & \\
\hline \multicolumn{5}{|l|}{$\mathrm{BW}(\mathrm{kg})$} \\
\hline d 1 & 43.6 & 44.6 & 0.72 & 0.34 \\
\hline d 42 & 62.0 & 71.1 & 1.17 & $<0.01$ \\
\hline d 56 & 75.9 & 81.9 & 1.29 & $<0.01$ \\
\hline \multicolumn{5}{|c|}{ ADG $(\mathrm{kg} / \mathrm{d})$} \\
\hline d 2 to 42 & 0.44 & 0.64 & 0.04 & $<0.01$ \\
\hline Gain:feed & 0.48 & 0.55 & 0.006 & $<0.01$ \\
\hline \multicolumn{5}{|c|}{ Withers height $(\mathrm{cm})$} \\
\hline d 7 & 77.4 & 78.0 & 0.33 & 0.60 \\
\hline d 42 & 83.6 & 86.3 & 0.54 & $<0.01$ \\
\hline \multicolumn{5}{|c|}{ Hip width $(\mathrm{cm})$} \\
\hline d 7 & 55.2 & 55.2 & 0.99 & 0.64 \\
\hline d 42 & 62.3 & 65.0 & 0.55 & $<0.01$ \\
\hline
\end{tabular}

${ }^{1}$ High-energy and high-protein diet.

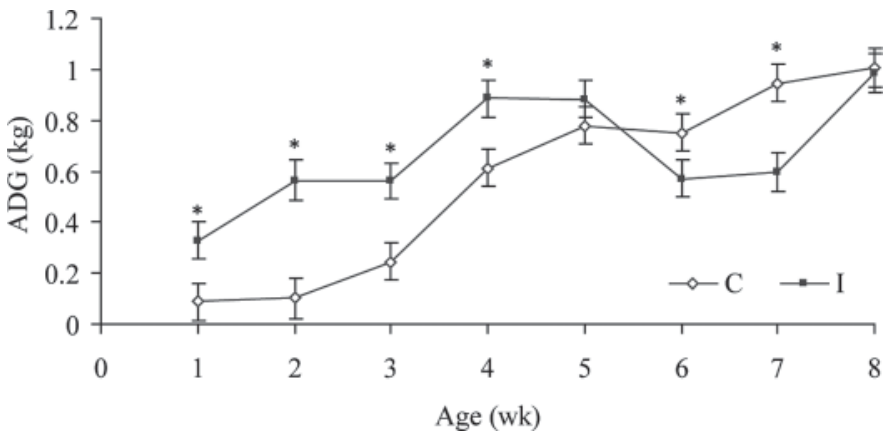

Figure 1. Effect of preweaning diet on daily gain averaged each week until 8 wk of age. Calves were fed either a conventional (C) or intensive (I; high-protein and high-energy) diet during the preweaning period. * indicates $P<0.05$.

$2 ; P<0.05)$. Calves fed the intensive diet remained larger, taller, and wider through 8 wk of age $(P<0.05)$.

Body weights measured every 4 wk after 8 wk of age were not different between treatments from 12 through 100 wk of age (Figure $3 ; P>0.1$ ). Heifers fed the intensive diet during the preweaning period were taller from 12 to $40 \mathrm{wk}$ and at $68 \mathrm{wk}$ of age, and tended to be taller at 44 and 72 through 84 wk of age (Figure $3 ; P<0.05$ and $P<0.1$, respectively). Heifers fed the intensive diet during the preweaning period tended to be wider at 12 wk of age and were wider at 16 through 24 wk of age (Figure 3; $P<0.1$ and $P<0.05$, respectively). Heifers fed the conventional diet tended to be wider at 84 and 100 wk of age $(P<0.1)$.

\section{Puberty}

Increasing the energy and protein intake of heifers during the preweaning period decreased age and BW at the onset of puberty (Table 8; $P<0.01$ and $P=$ 0.01 , respectively). Heifers fed the intensive compared with conventional energy and protein diet during the preweaning period were $31 \mathrm{~d}$ younger and $20 \mathrm{~kg}$ lighter at the onset of puberty. Heifers fed the intensive diet tended to be shorter at the onset of puberty $(P=0.10)$ and were narrower $(P<0.01)$. However, ADG measured from 6 wk of age until the onset of puberty was not different between treatments $(P=0.98)$.

\section{Breeding}

Heifers became eligible for breeding at $397 \mathrm{~kg}$ of BW. Body condition score at $397 \mathrm{~kg}$ did not differ between treatments (Table 8; $P=0.79$ ). At conception, heifers fed the high-energy and high-protein diet during the preweaning period were $15 \mathrm{~d}$ younger than heifers fed the conventional diet $(P=0.09)$. Daily gain from puberty to conception and $\mathrm{BW}$ at conception was not 

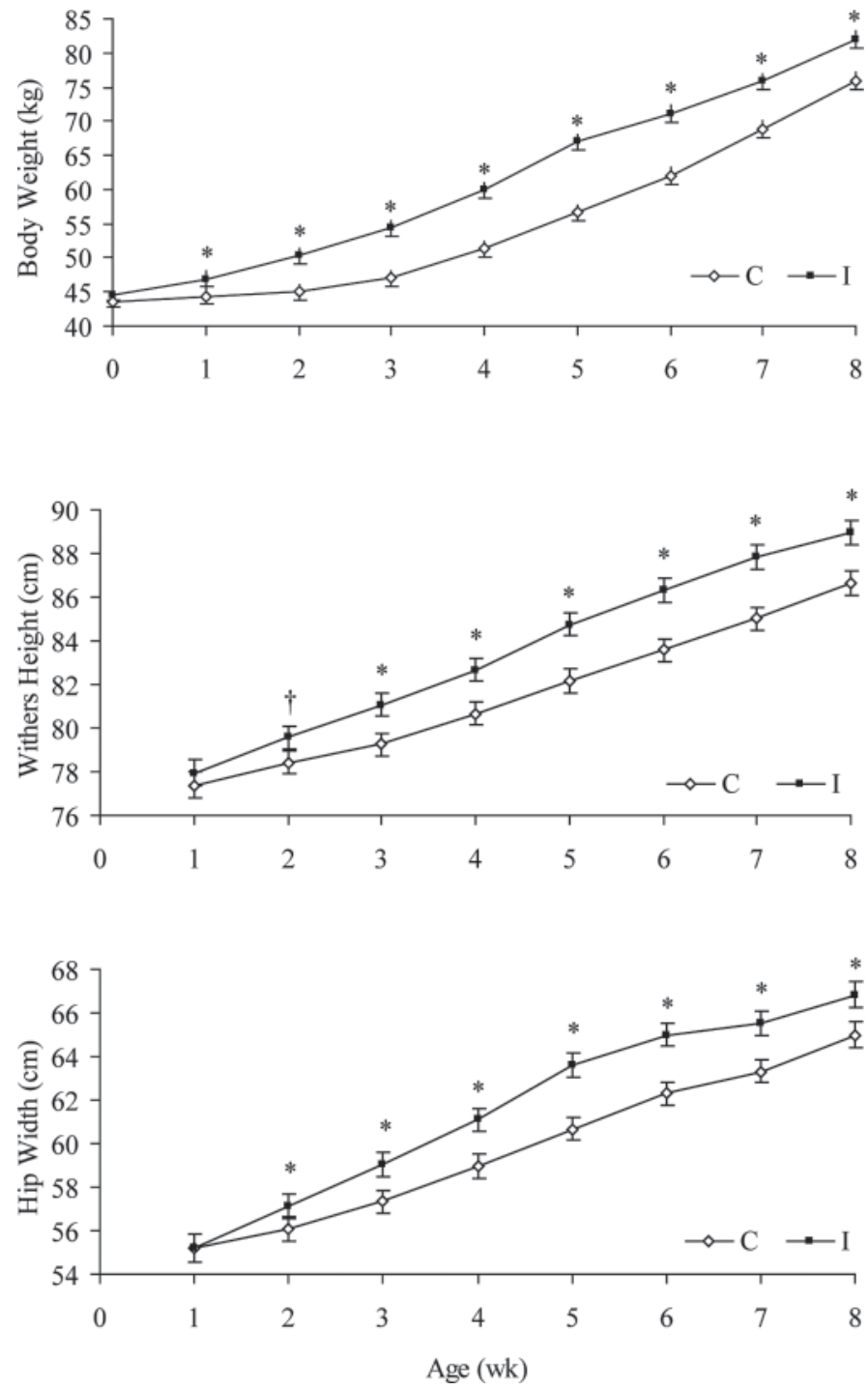

Figure 2. Effect of preweaning diet on BW, withers height, and hip width measurements taken weekly until 8 wk of age. Calves were fed either a conventional (C) or intensive (I; high-protein and high-energy) diet during the preweaning period. ${ }^{*}$ indicates $P<0.05$; $\dagger$ indicates $P<0.10$

different between treatments $(P>0.5)$. Withers height and services per conception were similar for both treatments $(P>0.9)$, but heifers fed the intensive diet were narrower at conception than those fed the conventional $\operatorname{diet}(P=0.04)$.

\section{Parturition}

Age at calving was $14 \mathrm{~d}$ earlier for those heifers fed the intensive diet during the preweaning period, but was not significant (Table 9; $P=0.11$ ). Body weights before and after calving were not different $(P=0.13$ and $P=0.11$, respectively). Withers height, daily gain

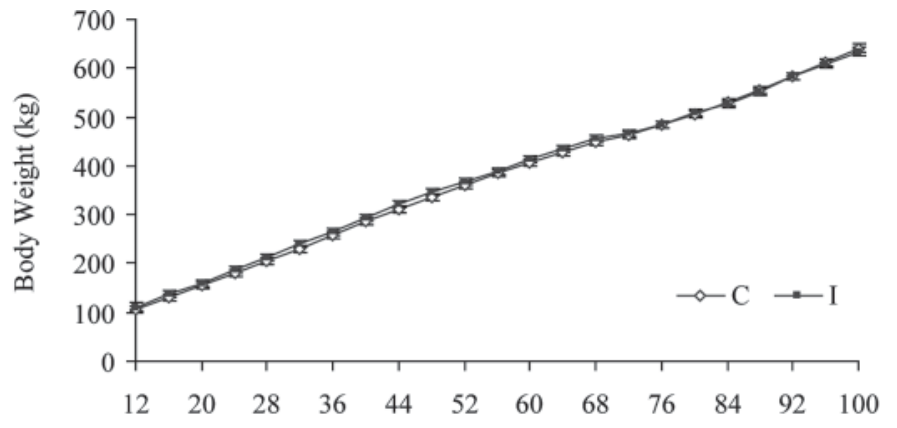

Age (wk)
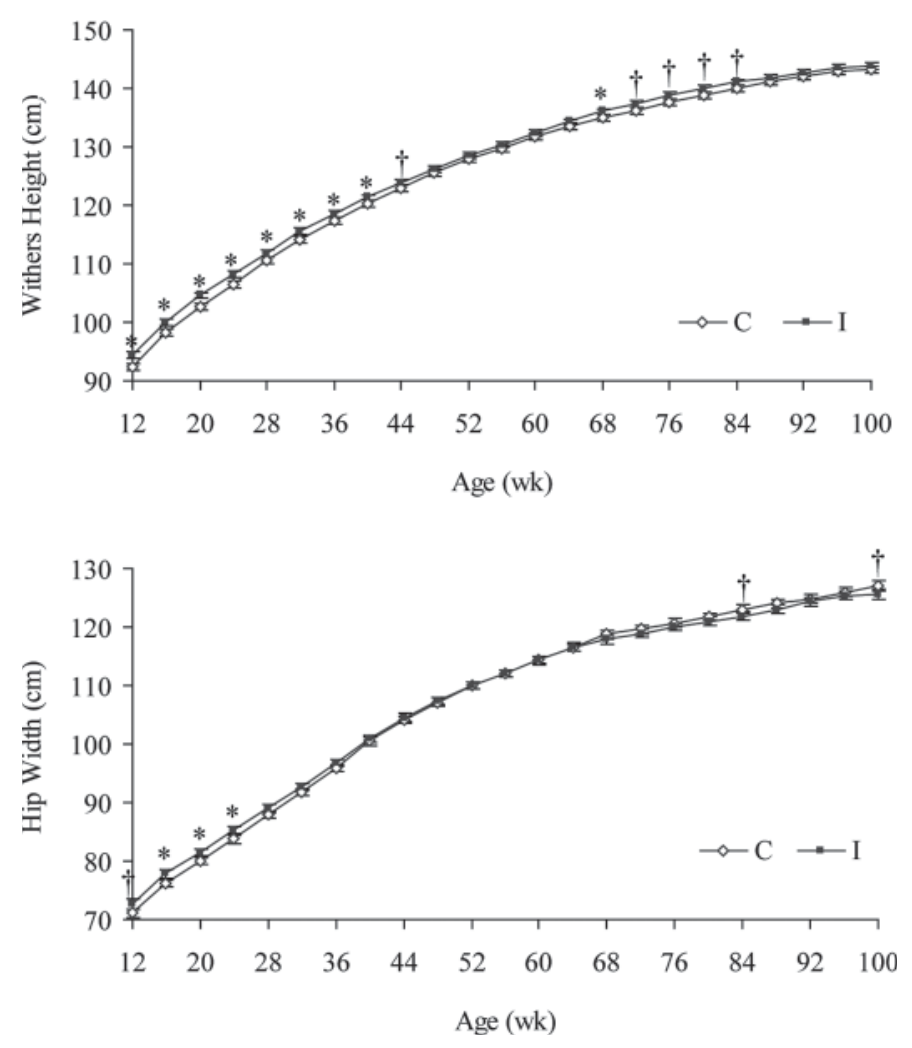

Figure 3. Effect of preweaning diet on BW, withers height, and hip width measurements taken every 4 wk during the post-treatment period. Calves were fed either a conventional (C) or intensive (I; highprotein and high-energy) diet during the preweaning period. * indicates $P<0.05 ; \dagger$ indicates $P<0.10$.

during gestation, BCS before calving, calving difficulty score, and calf BW were not different between treatments $(P \geq 0.14)$.

\section{Milk Yield}

Average daily milk through 150 DIM and milk yield (305-d, ECM) that was uncorrected for age was not significant and 305-d milk averaged 9,778 and 10,069 $\mathrm{kg}$ for heifers fed the conventional and intensive diets, 
Table 8. Effect of preweaning diet on puberty, breeding, and conception ${ }^{1}$

\begin{tabular}{|c|c|c|c|c|}
\hline \multirow[b]{2}{*}{ Item } & \multicolumn{2}{|c|}{ Preweaning diet } & \multirow[b]{2}{*}{ SEM } & \multirow[b]{2}{*}{$P$-value } \\
\hline & Conventional & Intensive $^{2}$ & & \\
\hline \multicolumn{5}{|l|}{ Onset of puberty } \\
\hline $\mathrm{n}$ & 39 & 39 & & \\
\hline Age (d) & 301 & 270 & 5.8 & $<0.01$ \\
\hline $\mathrm{BW}(\mathrm{kg})$ & 307 & 287 & 5.5 & 0.01 \\
\hline Withers height $(\mathrm{cm})$ & 122.3 & 120.9 & 0.61 & 0.10 \\
\hline Hip width $(\mathrm{cm})$ & 103.1 & 99.6 & 0.78 & $<0.01$ \\
\hline ADG $(\mathrm{kg} / \mathrm{d} ; 6$ wk-puberty $)$ & 0.95 & 0.95 & 0.01 & 0.98 \\
\hline \multicolumn{5}{|l|}{ Breeding and conception } \\
\hline $\mathrm{n}$ & 35 & 37 & & \\
\hline $\mathrm{BCS}$ at $397 \mathrm{~kg}$ of $\mathrm{BW}^{3}$ & 3.42 & 3.43 & 0.03 & 0.79 \\
\hline Age $(d)$ & 438 & 423 & 6.0 & 0.09 \\
\hline BW (kg) & 420 & 416 & 3.7 & 0.53 \\
\hline Withers height $(\mathrm{cm})$ & 133 & 133 & 0.47 & 0.96 \\
\hline Hip width $(\mathrm{cm})$ & 115.7 & 114.5 & 0.41 & 0.04 \\
\hline ADG (kg/d; puberty-conception) & 0.84 & 0.86 & 0.02 & 0.56 \\
\hline Services per conception ${ }^{4}$ & 1.20 & 1.19 & 0.09 & 0.93 \\
\hline
\end{tabular}

respectively (Table 10; $P=0.86$ and $P=0.27$ ). Analysis of milk yield (305-d ECM) with PA milk values as a covariate resulted in a tendency for heifers fed the intensive diet during the preweaning period to have greater milk yield when corrected for genetic variation (conventional $=9,712$ and intensive $=10,128 \mathrm{~kg} ; P=$ $0.08)$. Milk fat and milk protein percentages, and kilograms of milk fat and milk protein were not different (Table 10; $P \geq 0.15$ ). The PA values for milk (Table 10) were similar between treatments $(P=0.29)$. Both BW and withers height were not different between treatments when measured at 150 DIM (Table 10; $P>0.6$ ). However, heifers fed the conventional diet during the preweaning period tended to lose more weight during early lactation $(P=0.10)$.

\section{Economics}

Cost, revenue, and net return results are presented in Table 11. Milk replacer cost was significantly higher (Table 11; $P<0.01$ ) for the intensive treatment, whereas starter cost was significantly lower $(P<0.01)$. Total feed cost preweaning $(P<0.01)$ and total feed cost precalving $(P=0.02)$ were higher for animals fed the intensive diet. Heifer non-feed costs to 152 DIM and total heifer costs to 152 DIM did not differ $(P=0.11$ and $P=0.33$, respectively). Milk income $(P=0.27)$ and first lactation feed costs $(P=0.22)$ did not differ. In addition, no differences in net milk returns or in total milk and heifer returns were observed $(P=0.28$ and $P=0.51$, respectively). However, if milk yield is

Table 9. Effect of preweaning diet on parturition

\begin{tabular}{|c|c|c|c|c|}
\hline \multirow[b]{2}{*}{ Parturition measurement } & \multicolumn{2}{|c|}{ Preweaning diet } & \multirow[b]{2}{*}{ SEM } & \multirow[b]{2}{*}{$P$-value } \\
\hline & Conventional & Intensive $^{1}$ & & \\
\hline $\mathrm{n}$ & 33 & 34 & & \\
\hline Age (d) & 715 & 701 & 6.4 & 0.11 \\
\hline BW before calving $(\mathrm{kg})$ & 644 & 632 & 5.4 & 0.13 \\
\hline BW after calving ( $\mathrm{kg}$ ) & 574 & 563 & 5.2 & 0.11 \\
\hline Withers height $(\mathrm{cm})$ & 144 & 144 & 0.40 & 0.48 \\
\hline $\mathrm{ADG}$, gestation $(\mathrm{kg} / \mathrm{d})$ & 0.81 & 0.77 & 0.02 & 0.14 \\
\hline $\mathrm{BCS}^{2}$ & 3.47 & 3.46 & 0.02 & 0.71 \\
\hline Calving difficulty score ${ }^{2}$ & 2.13 & 2.14 & 0.20 & 0.97 \\
\hline Calf BW (kg) & 41.6 & 41.1 & 0.81 & 0.62 \\
\hline
\end{tabular}

${ }^{1}$ High-energy and high-protein diet.

${ }^{2} \mathrm{n}=32$ and 33 for conventional and intensive treatments, respectively. Calving difficulty scores were rated as follows: $1=$ no assistance; $2=$ slight assistance; $3=$ some assistance; $4=$ considerable force; $5=$ extreme difficulty. 
Table 10. Effect of preweaning diet on lactation

\begin{tabular}{|c|c|c|c|c|}
\hline \multirow[b]{2}{*}{ Item } & \multicolumn{2}{|c|}{ Preweaning diet } & \multirow[b]{2}{*}{ SEM } & \multirow[b]{2}{*}{$P$-value } \\
\hline & Conventional & Intensive $^{1}$ & & \\
\hline \multicolumn{5}{|l|}{ Lactation } \\
\hline $\mathrm{n}$ & 29 & 32 & & \\
\hline Average milk through 150 DIM $(\mathrm{kg} / \mathrm{d})$ & 33.1 & 33.3 & 0.83 & 0.86 \\
\hline Projected $305-\mathrm{d}$ milk $^{2}(\mathrm{~kg})$ & 9,778 & 10,069 & 187 & 0.27 \\
\hline PA-corrected milk $(\mathrm{kg})$ & 9,712 & 10,128 & 167 & 0.08 \\
\hline Milk fat ${ }^{2}(\%)$ & 4.11 & 4.15 & 0.08 & 0.74 \\
\hline Milk fat ${ }^{2}(\mathrm{~kg})$ & 372 & 386 & 6.71 & 0.15 \\
\hline Milk protein ${ }^{2}(\%)$ & 3.17 & 3.13 & 0.04 & 0.46 \\
\hline Milk protein ${ }^{2}(\mathrm{~kg})$ & 288 & 293 & 5.91 & 0.59 \\
\hline Milk PA value (kg) & 386 & 282 & 70.9 & 0.29 \\
\hline $\mathrm{SCC}(\times 1,000$ cells $/ \mathrm{mL})$ & 67.1 & 50.4 & 0.01 & 0.47 \\
\hline \multicolumn{5}{|l|}{ Growth at 150 DIM } \\
\hline BW $(\mathrm{kg})$ & 564 & 569 & 8.03 & 0.63 \\
\hline Withers height $(\mathrm{cm})$ & 144 & 144 & 0.53 & 0.98 \\
\hline Change in $\mathrm{BW}^{4}(\mathrm{~kg})$ & -10.6 & 6.6 & 7.5 & 0.10 \\
\hline
\end{tabular}

${ }^{1}$ High-energy and high-protein diet.

${ }^{2}$ Age-uncorrected ECM.

${ }^{3}$ Age-uncorrected ECM with parent average (PA) milk as a covariate.

${ }^{4}$ Change in BW reflects difference between BW after calving and BW at 150 DIM.

PA-corrected, then milk yield, and consequently, milk income, would tend to be higher for the heifers fed the intensive diet $(P=0.08$, see Table 10$)$.

Sensitivity analysis to changes in price and cost assumptions is displayed in Table 12. This table shows the net effect that price change had on raising costs of intensive growth versus conventional growth rates in calves and the net effect if all tested assumptions favored the intensive and conventional growth rates. Milk prices have been quite volatile in recent years so we examined a change of $40 \%$ in milk price. With a $40 \%$ increase, milk price was $\$ 22.40 / 45.4 \mathrm{~kg}$ and the net milk and total returns to the intensive treatment increased $\$ 41 /$ heifer. Other factors had a smaller influence on the economic costs and returns of the intensive relative to the conventional growth program. Increasing feed costs for postweaned heifers and lactating cows by $20 \%$ decreased heifer feed costs by $\$ 5$, decreased net milk returns $\$ 5 /$ heifer, and, thus, slightly decreased the economic value of the intensive diet. Labor and supply costs are also potentially important but tend to vary less than milk price and feed costs. In addition, even if labor and supply costs increased $5 \%$ specifically for the intensive treatment to cover extra bedding needs or health care, this would only be expected to raise the cost of the intensive treatment by $\$ 5 /$ heifer.

If all sensitivity assumptions were biased in favor of the intensive diet, the total return of the intensive diet increased to $\$ 102$, but this difference was still not statistically significant (Table $12 ; P=0.4$ ). If all assumptions were biased in favor of the conventional diet, the total return of the intensive diet was $-\$ 4$, so was slightly negative, but not statistically greater than $0(P$ $=0.9$ ). If milk was adjusted for PA, the total return to the intensive diet was $\$ 156(P=0.15)$ if all assumptions favored the intensive diet, and $\$ 10(P=0.6)$ if all assumptions favored the conventional diet.

\section{DISCUSSION}

Milk replacer is fed to heifer calves on most US dairy farms during some period before weaning (USDA, 2007). The advent of intensified feeding programs using milk replacer formulations more similar to whole milk has prompted evaluation of costs and benefits in comparison to more traditional milk replacers (Brown et al., 2005a,b; Cowles et al., 2006). However, few studies have focused on the long-term effects of intensified milk replacer feeding programs (Raeth-Knight et al., 2009). This paper compares the effects of intensified and conventional feeding programs for preweaned calves on growth, age at calving, milk yield, and economics.

\section{Preweaning Period}

Heifer calves had successful passive transfer of immunity at the beginning of the treatment period, based on serum $\operatorname{IgG}$ concentrations. Increasing the energy and protein intake of calves resulted in higher fecal scores and more days with loose stools. This was not surprising because others have indicated similar results (Brown et al., 2005b; Raeth-Knight et al., 2009). However, no treatment effect was observed for days treated for illness or days with a fever. The softer manure could be 
$\mathrm{kg} / \mathrm{d}$ during the preweaning period and calved $27.5 \mathrm{~d}$ earlier than calves fed a conventional milk replacer who gained $0.55 \mathrm{~kg} / \mathrm{d}$.

\section{Parturition}

Heifers calved at 23 and 23.5 mo for the intensive and conventional treatments, respectively. Body weights before parturition were slightly higher than standards set by Hoffman (1997) for heifers between 23 and 24 mo of age, but heifers were also approximately $5 \mathrm{~cm}$ taller than these standards. Body condition scores taken before parturition averaged 3.46 and were similar to the pre-calving BCS that yielded the greatest milk yield potential in a study by Waltner et al. (1993).

\section{Milk Yield}

Our original hypothesis was that increasing the energy and protein intake of preweaned calves would result in an earlier age at calving and increased first lactation milk yield. This hypothesis was based on earlier work indicating that calves that gained more during the preweaning period had increased mammary growth (Brown et al., 2005a), and calves consuming whole milk gained faster and produced more milk in their first lactation (Bar-Peled et al., 1997; Shamay et al., 2005). Results from this study indicate that calves fed milk replacer for increased energy and protein intake tended to conceive and calve at a younger age when bred at the same BW as calves fed conventional levels. Average daily milk yield through 150 DIM and projected 305-d ECM yield that was age uncorrected was not different between treatments. These results are similar to those of Raeth-Knight et al. (2009). However, we did see a tendency for an increase in first lactation milk yield in animals fed the intensive diet when data was corrected for genetic variation (PA covariate).

Calves in the present study were treated similarly to those of Brown et al. (2005a), were fed the same milk replacers, and had similar BW gain. Brown et al. (2005a) found that increasing the energy and protein intake in calves from 2 to 8 wk of age almost doubled the amount of mammary parenchymal DNA and increased the amount of mammary parenchymal tissue at weaning. In the present study, we observed a $3.5 \%$ increase in milk from heifers fed the intensive diet during the preweaning period. The mammary gland grows at an allometric rate until around the onset of puberty and then becomes isometric relative to overall body growth (Sinha and Tucker, 1969). Calves that were fed the intensive diet reached the onset of puberty 1 mo earlier than calves fed the conventional diet. The potential increase in mammary growth of calves as seen in the Brown et al. (2005a) study may have been negated by a shorter duration of allometric mammary growth. In addition, the rate of mammary epithelial cell proliferation at $14 \mathrm{wk}$ of age was higher in calves fed a conventional diet before weaning, even though total parenchymal mass, DNA, and RNA were higher for calves fed a high diet (Brown et al., 2005a). Thus, we suggest that calves fed for conventional rates of growth before weaning may experience more rapid mammary development after weaning.

\section{Economics}

Although feed efficiency was greater for calves on the intensified feeding program, feed costs/d averaged $\$ 1.27$ higher for the intensified program. These results are similar to those presented in Brown et al. (2005b) and Raeth-Knight et al. (2009). The number of nonproductive days was decreased an average of $14 \mathrm{~d}$ by increasing the energy and protein intake of calves during the preweaning period.

Despite the fact that milk replacer costs of the intensified calves were much greater, the decrease in nonproductive days and a trend toward higher milk yield of these calves later in life resulted in no difference in total returns. In fact, our data support the idea that the net return could be almost 3 times the initial extra cost of the intensive milk replacer and likely would not be negative. This suggests that the decision about whether to use intensified milk feeding programs should be based on other factors.

\section{CONCLUSIONS}

Heifer calves consuming higher levels of energy and protein during the preweaning period had a larger BW, withers height, and hip width at weaning than did calves consuming a conventional diet. Calves fed the intensive diet had higher fecal scores but no difference in health status was observed. Heifers fed the intensive preweaning diet reached puberty at a younger age and lighter body weight. These heifers also tended to be younger at conception and calving. Age-uncorrected ECM was not different between treatments, but when genetic variation was removed, milk yield tended to be higher in those animals fed the intensive diet during the preweaning period. Economically, the 2 programs were not significantly different, indicating that farms can consider other operation-specific management factors in selection of a feeding program for calves.

\section{ACKNOWLEDGMENTS}

The authors thank the farm staff at the Michigan State University (MSU) Dairy Farm (East Lansing) 
for managing and feeding the heifers, and collecting milk data. The authors thank MSC Specialty Nutrition (Dundee, IL) and Kent Feeds (Muscatine, IA) for their generous provision of milk replacer and starter grain, respectively, used in this study. The authors thank Ted Ferris (MSU) for his help on gathering and analyzing milk data. This research was supported by a grant from the MSU Animal Agriculture Initiative.

\section{REFERENCES}

Bar-Peled, U., B. Robinzon, E. Maltz, H. Tagari, Y. Folman, I. Bruckental, H. Voet, H. Gacitua, and A. R. Lehrer. 1997. Increased weight gain and effects on production parameters of Holstein heifer calves that were allowed to suckle from birth to six weeks of age. J. Dairy Sci. 80:2523-2528.

Brown, E. G., M. J. VandeHaar, K. M. Daniels, J. S. Liesman, L. T. Chapin, J. W. Forrest, R. M. Akers, R. E. Pearson, and M. S. Weber Nielsen. 2005a. Effect of increasing energy and protein intake on mammary development in heifer calves. J. Dairy Sci. 88:595-603.

Brown, E. G., M. J. VandeHaar, K. M. Daniels, J. S. Liesman, L. T. Chapin, D. H. Keisler, and M. S. Weber Nielsen. 2005b. Effect of increasing energy and protein intake on body growth and carcass composition of heifer calves. J. Dairy Sci. 88:585-594.

Cowles, K. E., R. A. White, N. L. Whitehouse, and P. S. Erickson. 2006. Growth characteristics of calves fed an intensified milk replacer regimen with additional lactoferrin. J. Dairy Sci. 89:48354845.

Dhuyvetter, K. C., M. Brouk, J. F. Smith, and J. P. Harner III. 2005. Raising dairy herd replacements. Kansas State University Department of Agricultural Economics Farm Management Guide MF399. Accessed June 12, 2009. http://www.oznet.ksu.edu/library/ agec2/mf399.pdf.

Dingwell, R. T., M. M. Wallace, C. J. McLaren, C. F. Leslie, and K. E. Leslie. 2006. An evaluation of two indirect methods of estimating body weight in Holstein calves and heifers. J. Dairy Sci. 89:3992-3998.

Harsh, S. B., C. Wolf, and E. Wittenberg. 2001. Profitability and production efficiency of the crop and livestock enterprises of Michigan dairy operations: 1998 summary and analysis. Michigan State University Ag Econ Staff Paper 2001-04. Accessed June 12, 2009. http://purl.umn.edu/11616.

Hoffman, P. C. 1997. Optimum body size of Holstein replacement heifers. J. Anim. Sci. 75:836-845.

Huber, J. T., A. G. Silva, O. F. Campos, and C. M. Mathieu. 1984. Influence of feeding different amounts of milk on performance, health, and absorption capability of baby calves. J. Dairy Sci. 67:2957-2963.

Norman, H. D., P. D. Miller, B. T. McDaniel, F. N. Dickinson, and C.R. Henderson. 1974. USDA-DHIA factors for standardizing 305- day lactation records for age and month of calving. USDA Agric. Res. Serv. ARS-NE-40. USDA, Washington, DC.

NRC. 2001. Nutrient Requirements of Dairy Cattle. 7th rev. ed. Natl. Acad. Sci., Washington, DC.

Pennsylvania State University College of Agricultural Sciences Agricultural Research and Cooperative Extension. 2000. Dairy heifer production. Accessed June 12, 2009. http://agalternatives.aers. psu.edu/Publications/Dairy_Heifer.pdf.

Petitclerc, D., P. Dumoulin, H. Ringuet, J. Matte, and C. Girard. 1999. Plane of nutrition and folic acid supplementation between birth and four months of age on mammary development of dairy heifers. Can. J. Anim. Sci. 79:227-234.

Quigley, J. D., T. A. Wolfe, and T. H. Elsasser. 2006. Effects of additional milk replacer feeding on calf health, growth, and selected blood metabolites in calves. J. Dairy Sci. 89:207-216.

Radcliff, R. P., M. J. Vandehaar, L. T. Chapin, T. E. Pilbeam, D. K. Beede, E. P. Stanisiewski, and H. A. Tucker. 2000. Effects of diet and injection of bovine somatotropin on prepubertal growth and first-lactation milk yields of Holstein cows. J. Dairy Sci. 83:23-29.

Radcliff, R. P., M. J. Vandehaar, A. L. Skidmore, L. T. Chapin, B. R. Radke, J. W. Lloyd, E. P. Stanisiewski, and H. A. Tucker. 1997. Effects of diet and bovine somatotropin on heifer growth and mammary development. J. Dairy Sci. 80:1996-2003.

Raeth-Knight, M., H. Chester-Jones, S. Hayes, J. Linn, R. Larson, D. Ziegler, B. Zeigler, and N. Broadwater. 2009. Impact of conventional or intensive milk replacer programs on Holstein heifer performance through six months of age and during first lactation. J. Dairy Sci. 92:799-809.

SAS Institute. 2004. SAS/STAT User's Guide. Version 9. SAS Institute Inc., Cary, NC.

Schillo, K. K., J. B. Hall, and S. M. Hileman. 1992. Effects of nutrition and season on the onset of puberty in the beef heifer. J. Anim. Sci. 70:3994-4005.

Sejrsen, K., J. T. Huber, H. A. Tucker, and R. M. Akers. 1982. Influence of nutrition of mammary development in pre- and postpubertal heifers. J. Dairy Sci. 65:793-800.

Shamay, A., D. Werner, U. Moallem, H. Barash, and I. Bruckental. 2005. Effect of nursing management and skeletal size at weaning on puberty, skeletal growth rate, and milk production during first lactation of dairy heifers. J. Dairy Sci. 88:1460-1469.

Sinha, Y. N., and H. A. Tucker. 1969. Mammary development and pituitary prolactin levels of heifers from birth through puberty and during the estrous cycle. J. Dairy Sci. 52:507-512.

USDA. 2007. Dairy 2007, Part I: Reference of dairy cattle health and management in the United States, 2007. USDA-APHIS-VS, CEAH \#N480.1007. National Animal Health Monitoring System, Fort Collins, CO.

USDA-NASS. 2008. Agricultural prices monthly. National Agricultural Statistics Service. Accessed October 20, 2009. http://usda.mannlib. cornell.edu/MannUsda/viewDocumentInfo.do?documentID=1003.

Waltner, S. S., J. P. McNamara, and J. K. Hillers. 1993. Relationships of body condition score to production variable in high producing Holstein dairy cattle. J. Dairy Sci. 76:3410-3419. 